\title{
Effect of subtherapeutic vs. therapeutic administration of macrolides on antimicrobial resistance in Mannheimia haemolytica and enterococci isolated from beef cattle
}

\section{Rahat Zaheer ${ }^{1}$, Shaun R. Cook ${ }^{1}$, Cassidy L. Klima ${ }^{1}$, Kim Stanford ${ }^{2}$, Trevor Alexander ${ }^{1}$, Edward Topp ${ }^{3}$, Ron R. Read ${ }^{4}$ and Tim A. McAllister ${ }^{1 *}$}

${ }_{1}^{1}$ Lethbridge Research Centre, Agriculture and Agri-Food Canada, Lethbridge, AB, Canada

2 Alberta Agriculture and Rural Development, Lethbridge, $A B$, Canada

${ }^{3}$ Southern Crop Protection and Food Research Centre, Agriculture and Agri-Food Canada, London, ON, Canada

${ }^{4}$ Faculty of Medicine, University of Calgary, Calgary, AB, Canada

Edited by:

Marilyn C. Roberts, University of Washington, USA

Reviewed by:

Marilyn C. Roberts, University of Washington, USA

Henk Aarts, National Institute for

Public Health and the Environment, Netherlands

Michael T. Sweeney, Zoetis, USA

\section{*Correspondence:}

Tim A. McAllister, Lethbridge

Research Center, Agriculture and Agri-Food Canada, 5403-1st Ave.

South, Lethbridge, AB T1J 4B1,

Canada.

e-mail: tim.mcallister@agr.gc.ca
Macrolides are the first-line treatment against bovine respiratory disease (BRD), and are also used to treat infections in humans. The macrolide, tylosin phosphate, is often included in the diet of cattle as a preventative for liver abscesses in many regions of the world outside of Europe. This study investigated the effects of administering macrolides to beef cattle either systemically through a single subcutaneous injection (therapeutic) or continuously in-feed (subtherapeutic), on the prevalence and antimicrobial resistance of Mannheimia haemolytica and Enterococcus spp. isolated from the nasopharynx and faeces, respectively. Nasopharyngeal and faecal samples were collected weekly over 28 days from untreated beef steers and from steers injected once with tilmicosin or tulathromycin or continuously fed tylosin phosphate at dosages recommended by manufacturers. Tilmicosin and tulathromycin were effective in lowering $(P<0.05)$ the prevalence of $M$. haemolytica, whereas subtherapeutic tylosin had no effect. $M$. haemolytica isolated from control- and macrolide-treated animals were susceptible to macrolides as well as to other antibiotics. Major bacteria co-isolated with $M$. haemolytica from the nasopharynx included Pasteurella multocida, Staphylococcus spp., Acinetobacter spp., Escherichia coli and Bacillus spp. With the exception of M. haemolytica and P. multocida, erythromycin resistance was frequently found in other isolated species. Both methods of macrolide administration increased $(P<0.05)$ the proportion of erythromycin resistant enterococci within the population, which was comprised almost exclusively of Enterococcus hirae. Injectable macrolides impacted both respiratory and enteric microbes, whereas orally administered macrolides only influenced enteric bacteria.

Keywords: macrolides, antimicrobial resistance, Mannheimia haemolytica, enterococci, beef cattle

\section{INTRODUCTION}

Bovine respiratory disease (BRD), commonly known as shipping fever continues to be one of the most economically significant health issues in feedlot cattle. The pathogenesis of BRD is multifactorial, being influenced by stress, immune status as well as viral/bacterial interactions within the respiratory tract. Regardless of what initiates the disease, Mannheimia haemolytica is considered to be the predominant bacterial pathogen associated with BRD (Confer, 2009).

To reduce or treat $\mathrm{BRD}$, antibiotics are commonly administered to cattle upon arrival in North American feedlots. The use of antimicrobial therapy to control BRD increases in high-density feedlots where conditions are favorable for the introduction and transmission of infectious microbes. The macrolides, tilmicosin and tulathromycin are frequently administered subcutaneously to high-risk cattle, either prophylactically, metaphylactically, or therapeutically to cattle suffering from the disease. In North America, the macrolide tylosin phosphate is also included in beef cattle diets as a growth promoter and to prevent liver abscesses, a practice banned in Europe. After ionophores and tetracycline, macrolides are the most frequently used antimicrobials in cattle production in Canada (CIPARS, 2013). In the United States, a survey of $84 \%$ of the US feedlots revealed that about $42 \%$ of cattle received tylosin in feed for 138-145 days whereas over two-thirds of the cattle received injectable macrolides (USDA, 1999).

Macrolides belonging to the antimicrobial drug superfamily $\mathrm{MLS}_{\mathrm{B}}$ (macrolide-lincosamide-streptogramin B) are classified as category II antimicrobials by the WHO and Health Canada (http://hc-sc.gc.ca/dhp-mps/vet/antimicrob/amr_ram_hum-medrev-eng.php) emphasizing their importance in treating infections in humans. As reviewed by Gow (2005), as a proportion of total DDDs (Defined Daily Dose) for humans, after penicillins (27\%), macrolides (20\%) constitute the second most common systemic antibacterial class dispensed by retail pharmacies in Canada, followed by tetracyclines (14\%), fluoroquinolones (12\%), firstand second-generation cephalosporins (10\%). 
Although tilmicosin, tulathromycin and tylosin are exclusively used in food animals, they belong to the same category II MLS superfamily as erythromycin, which is used in both humans, food and companion animals. Despite having slight structural differences these drugs cross-select for resistance to all drugs of this superfamily, including several drugs used to treat infections in humans such as erythromycin and its derivatives azithromycin and clarithromycin (Roberts, 2008; Desmolaize et al., 2011). Consequently, use of macrolides in livestock could affect the efficacy of these antibiotics in controlling infections in humans through selection for resistance. Macrolide resistance can be conferred by discrete point mutations at nucleotide A2058 and its neighbours in the $23 \mathrm{~S}$ rRNA, altering the main anchoring point for these antibiotics (Schlünzen et al., 2001) or by methylation of the A2058 at the N6 position as catalyzed by the Erm family of methyltransferases (Skinner et al., 1983). Drug efflux systems have also been shown to result in macrolide resistance (Roberts et al., 1999).

Enterococci are common members of the normal gut flora of both livestock and humans (Yost et al., 2011), but they can also be important human pathogens as Enterococcus faecalis and Enterococcus faecium are often implicated in nosocomial infections. Macrolide resistant enterococci have been isolated from cattle and depending on the species, could potentially colonize the intestinal tract of humans if they enter the food chain (Giraffa, 2002; Jensen et al., 2002).

The present study investigated and compared the response of respiratory and digestive tract bacteria in feedlot cattle to no antibiotic treatment or treatment with macrolide antibiotics at subtherapeutic (in-feed) or therapeutic (via injection) levels. Our specific objective was to evaluate the effects of administering macrolides to beef cattle either systemically through a single subcutaneous injection (tilmicosin and tulathromycin) or continuously in-feed (tylosin phosphate), on the prevalence and the antimicrobial resistance profiles of faecal Enterococcus spp., and M. haemolytica from the nasopharynx.

\section{MATERIALS AND METHODS EXPERIMENTAL DESIGN}

The study was conducted at the individual feeding barn facility at the Lethbridge Research Centre (Lethbridge, Alberta, Canada) using 40-eleven month old beef steers $(394 \pm 37 \mathrm{~kg})$. All steers originated from the same ranch and had not received antibiotics during their lifetime prior to their arrival at the Lethbridge Research Centre. Steers were housed in individual pens with 10 replicate animals for each of the four treatments (1) control, no antibiotics; (2) tilmicosin (Micotil ${ }^{\circledR}$ Elanco Animal Health) single subcutaneous injection at $10 \mathrm{mg} / \mathrm{kg}$ bodyweight (BW) on day 1 ; (3) tulathromycin (Draxxin ${ }^{\circledR}$ Pfizer Animal Health, www.pfizer. ca) single subcutaneous injection at $2.5 \mathrm{mg} / \mathrm{kg}$ BW on day 1 ; (4) tylosin phosphate $\left(\operatorname{Tylan}^{\circledR}\right.$, Elanco Animal Health, www. elanco.ca) at $11 \mathrm{ppm}$ in feed for the entire 28 day experimental period (Figure 1). Adjacent pens within the same treatment group shared a common water trough and cattle within each treatment were housed in separate, but otherwise identical wings of the barn. Throughout the study, care of the steers was in accordance with the guidelines set by the Canadian Council on Animal Care (http://www.ccac.ca/).

\section{DIET AND FEEDING}

Steers were housed in individual pens and fed a typical foragebased growing diet consisting of 70\% barley silage, 25\% barley grain, and 5\% supplement (Addah et al., 2011) on a dry matter (DM) basis, for the entire experimental period (Figure 1). Steers were fed once daily in a manner that ensured that all feed that was allotted was consumed. To avoid cross contamination of feed, tylosin was mixed with $5 \mathrm{~kg}$ of supplement and manually spread over the surface of feed within each of the appropriate pens during the morning feeding. All cattle were provided feed at the same time each day with no feed remaining in the bunk prior to the next feeding. Cattle assigned to the control treatment had no access to medicated feed throughout the entire experiment and were not injected with any antibiotics.

\section{SAMPLING AND SAMPLE PROCESSING}

Rectal faecal and nasopharyngeal swab samples were taken from all 40 animals on arrival (day 0) at the facility, and then weekly thereafter for 4 weeks and processed as follows:

\section{Faecal samples}

Rectal grab faecal samples were taken and used for subsequent determination of antimicrobial resistant and total numbers of enterococci bacteria. For the isolation of Enterococcus species faecal samples $(1 \mathrm{~g})$ were diluted 1:5 in phosphate buffered saline, from which serial dilutions were made up to $10^{-5}$ and $100 \mu \mathrm{L}$ of each dilution was spread-plated, in duplicate, onto Bile-Esculin-Azide (BEA) agar plates. Dilutions $10^{-1}$ and $10^{-2}$ were also spread-plated onto BEA agar containing erythromycin at a concentration of $8 \mu \mathrm{g} / \mathrm{mL}$ of media (BEA+Ery) to isolate macrolide-resistant enterococci. Plates were incubated at $37^{\circ} \mathrm{C}$ for $24 \mathrm{~h}$ and colonies from both BEA and BEA+Ery plates were enumerated. Three to five presumptive Enterococcus colonies per sample per media type were isolated and streakpurified onto BEA or BEA+Ery plates accordingly. Purified isolates were stored in glycerol stocks at $-80^{\circ} \mathrm{C}$ until further characterized.

\section{Nasopharyngeal swab samples}

Nasopharyngeal swab samples were collected using a commercially available deep, double guarded culture swab (Jorgensen Laboratories, Inc., Loveland, CO, USA) from all 40 steers on arrival at the beef-barn facility prior to administration of antibiotics, and then weekly thereafter for 4 weeks following antibiotic treatment. Swab samples were transported to the lab on ice and immediately suspended in $0.7 \mathrm{~mL}$ of Brain Heart Infusion (BHI) broth. Aliquots $(100 \mu \mathrm{L})$ were cultured at $37^{\circ} \mathrm{C}$ for $16 \mathrm{~h}$ onto BAC-agar plates (tryptic soy agar plates containing $5 \%$ sheep blood and $15 \mu \mathrm{g} / \mathrm{mL}$ of bacitracin; Dalynn Biologicals, Inc., Calgary, $\mathrm{AB}$, Canada) with and without the addition of erythromycin (Ery) $8 \mu \mathrm{g} / \mathrm{mL}$ at $37^{\circ} \mathrm{C}$ for $16 \mathrm{~h}$. Colonies (1-5) indicative of Mannheimia, were selected and tested for catalase and oxidase activity as described previously (Klima et al., 2011). Isolates that exhibited typical M. haemolytica 


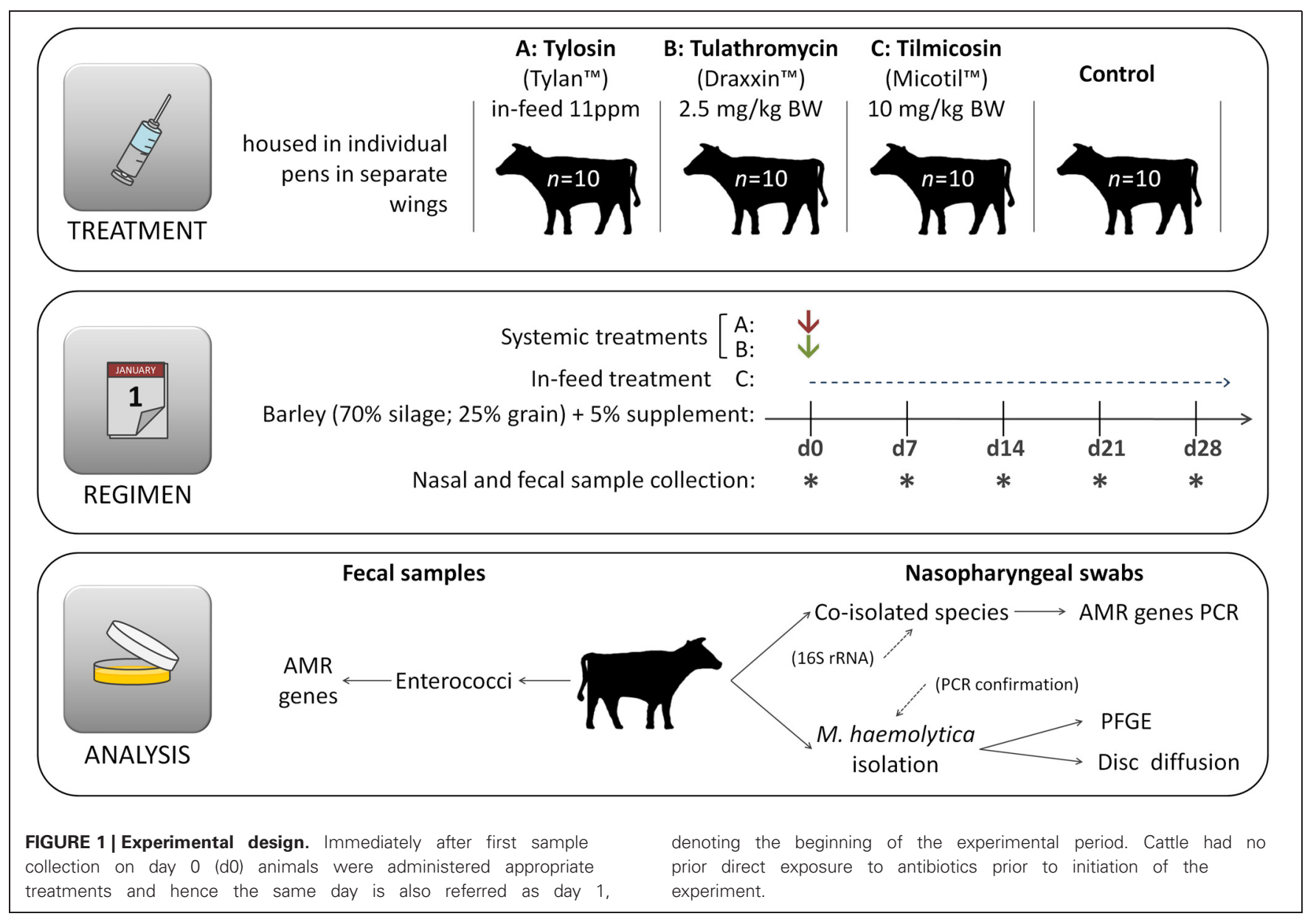

colony morphology and were both catalase and oxidase positive were subsequently confirmed using a multiplex PCR assay (Alexander et al., 2008). Confirmed M. haemolytica isolates were stored at $-80^{\circ} \mathrm{C}$ in BHI broth containing $20 \%$ glycerol for further characterization. Colonies that did not exhibit morphology indicative of Mannheimia on BAC or BAC+Ery agar plates were identified and 1-2 colonies representing each morphotype were selected and stored at $-80^{\circ} \mathrm{C}$ in BHI broth containing $20 \%$ glycerol until further characterized. Bacitracin in BAC media inhibited the growth of the majority of gram positive bacteria, thereby improving the likelihood of isolating M. haemolytica. Although bacitracin resistant gram positive bacteria were co-isolated with Mannheimia, these isolates were subsequently identified using 16S rRNA profiling as described below.

\section{CHARACTERIZATION OF Mannheimia haemolytica AND CO-ISOLATED NASOPHARYNGEAL BACTERIA}

Confirmed M. haemolytica isolates were serotyped as previously described (Klima et al., 2011) with antisera prepared in rabbits against formalin-killed whole cells of $M$. haemolytica reference strains UGCC G1 (serotype 1), UGCC G2 (serotype 2), ATCC 29697 (serotype 6), ATCC 29698 (serotype 7), and ATCC 29700 (serotype 9). Isolates were subject to pulsed field gel electrophoresis (PFGE) profiling using SalI restriction enzyme as previously described (Klima et al., 2011). The 16S rRNA genes were PCR amplified from bacteria coisolated with $M$. haemolytica using universal bacterial $16 \mathrm{~S}$ rRNA gene primers 27F (5'-AGAGTTTGATCCTGGCTCAG-3') and 1492R (5'-GGTTACCTTGTTACGACTT-3') and subject to DNA sequencing (Eurofins MWG Operon, Huntsville, Alabama, USA) using one (27F) or both (27F and 1492R) primers.

\section{ANTIBIOGRAMS}

Disk susceptibility tests were conducted for Mannheimia in accordance with the Clinical and Laboratory Standards Institute documents M31-A3 and M45-A (CLSI, 2008a,b). The antimicrobials tested, suppliers and resistance breakpoints applied are listed in Table 1. Reference strains Escherichia coli ATCC 35218, Staphylococcus aureus ATCC 25923, Streptococcus pneumoniae ATCC 49619, and M. haemolytica ATCC 33396 were used as quality controls. Briefly, cultures grown on Muller-Hinton agar supplemented with 5\% defibrinated sheep blood (MHB; $16-18 \mathrm{~h}$ at $37^{\circ} \mathrm{C}$ ) were suspended into Muller-Hinton broth to an absorbance reading between 0.125 and 0.145 at $625 \mathrm{~nm}$. Using sterile swabs, the prepared inocula were swabbed onto MHB followed by the dispensation of the antibiotic containing disks onto the plate surface. The plates were incubated at $37^{\circ} \mathrm{C}$ in ambient air, with the exception of S. pneumoniae ATCC 49619 which required cultivation in a $5 \% \mathrm{CO}_{2}$ atmosphere for $24 \mathrm{~h}$. 
Table 1 | Antimicrobial agents, suppliers, disk contents, and interpretative criteria used for disk susceptibility testing.

\begin{tabular}{|c|c|c|c|c|c|c|}
\hline \multirow[t]{2}{*}{ Antimicrobial } & \multirow[t]{2}{*}{ Supplier } & \multirow[t]{2}{*}{ Supplier code } & \multirow[t]{2}{*}{ Disk content $(\mu \mathrm{g})$} & \multicolumn{3}{|c|}{ Zone diameter $(\mathrm{mm})$ breakpoints ${ }^{c}$} \\
\hline & & & & $\mathbf{S}$ & I & $\mathbf{R}$ \\
\hline Amoxicillin/clavulanic Acid ${ }^{a}$ & $\mathrm{BD}$ & AMC-30 & $20 / 10$ & $\geq 27$ & $\mathrm{n} / \mathrm{a}$ & $\leq 26$ \\
\hline Ampicillin ${ }^{a}$ & $\mathrm{BD}$ & AM-10 & 10 & $\geq 27$ & $\mathrm{n} / \mathrm{a}$ & $\mathrm{n} / \mathrm{a}$ \\
\hline Ceftiofur ${ }^{b}$ & $\mathrm{BD}$ & XNL-30 & 30 & $\geq 21$ & $18-20$ & $\leq 17$ \\
\hline Danofloxacin ${ }^{b}$ & Pfizer & DNO & 5 & $\geq 22$ & $\mathrm{n} / \mathrm{a}$ & $\mathrm{n} / \mathrm{a}$ \\
\hline Erythromycin ${ }^{a}$ & $\mathrm{BD}$ & E-15 & 15 & $\geq 27$ & $25-26$ & $\leq 24$ \\
\hline Florfenicol ${ }^{b}$ & $\mathrm{BD}$ & FF-30 & 30 & $\geq 19$ & $15-18$ & $\leq 14$ \\
\hline Gentamicin $^{\mathrm{b}}$ & $\mathrm{BD}$ & GM-10 & 10 & $\geq 15$ & $13-14$ & $\leq 12$ \\
\hline Oxytetracycline ${ }^{a}$ & $\mathrm{BD}$ & $\mathrm{T}-30$ & 30 & $\geq 23$ & $\mathrm{n} / \mathrm{a}$ & $\mathrm{n} / \mathrm{a}$ \\
\hline Spectinomycin ${ }^{\mathrm{b}}$ & $\mathrm{BD}$ & SPT-100 & 100 & $\geq 14$ & $11-13$ & $\leq 10$ \\
\hline Sulfamethoxazole ${ }^{a} /$ trimethoprim & $\mathrm{BD}$ & SXT & $23.75 / 1.25$ & $\leq 24$ & $\mathrm{n} / \mathrm{a}$ & $\mathrm{n} / \mathrm{a}$ \\
\hline Tilmicosin ${ }^{b}$ & $\mathrm{BD}$ & TIL-15 & 15 & $\geq 14$ & $11-13$ & $\leq 10$ \\
\hline Tulathromycin ${ }^{b}$ & Pfizer & TUL & 30 & $\geq 18$ & $15-17$ & $\leq 14$ \\
\hline
\end{tabular}

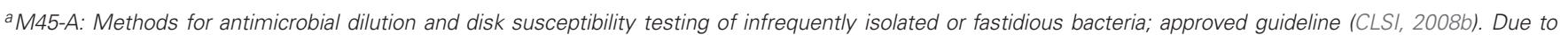
the unavailability MIC breakpoints for Mannheimia spp., guidelines for Pasteurella spp. were followed.

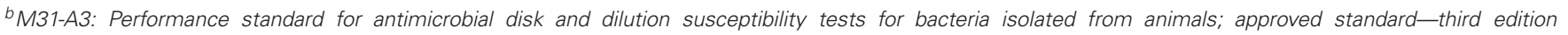
(CLSI, 2008a).

${ }^{c}$ Zone diameter value used to indicate susceptible (S), intermediate (I) and resistant (R), n/a, not available.

The resulting zones of inhibition were read using the BioMic V3 imaging system (Giles Scientific, Inc., Santa Barbara, CA, USA).

\section{CHARACTERIZATION OF ENTEROCOCCI}

The enterococci isolated from faecal samples were confirmed to be Enterococcus spp. by PCR using primers Ent-ES-211-233-F (5'-GHACAGAAGTRAAATAYGAAGG-3') and Ent-EL-74-95-R (5'-GGNCCTAABGTHACTTTNACTG-3') and 130 select isolates representing both erythromycin susceptible and resistant categories were further analyzed for species identification by pyrosequencing as described by Zaheer et al. (2012). Thirty six select isolates were subject to PFGE profiling using SmaI restriction enzyme using an adaptation of the procedure of Turabelidze et al. (2000). Briefly, bacteria from overnight brainheart infusion-agar (BHI-agar) cultures were harvested using sterile swabs and suspended in cell suspension buffer [100 mM Tris- $\mathrm{HCl}(\mathrm{pH} 8.0)$ and $100 \mathrm{mM}$ EDTA], to an optical density (OD) of $1.2-1.3$ at $610 \mathrm{~nm}(1-\mathrm{cm}$ light path). Aliquots $(1 \mathrm{ml}$ each) of the suspensions were centrifuged $(10,000 \times \mathrm{g})$ for $2 \mathrm{~min}$. in a microcentrifuge and $2 / 3 \mathrm{rd}$ of the supernatant was removed from the tube. The bacterial pellet was resuspended in the remaining supernatant, concentrating the cell suspension to an $\mathrm{OD}_{610}$ of 3.6-4.0 (ca. $\left.2.5 \times 10^{9} \mathrm{CFU} / \mathrm{ml}\right)$. An aliquot $(100 \mu \mathrm{L})$ of cell suspension was added to an equal volume of lysis buffer (50 mM Tris- $\mathrm{HCl}$ (pH 8), 50 mM EDTA, $625 \mathrm{U} / \mathrm{ml}$ mutanolysin, $2.5 \mathrm{mg} / \mathrm{ml}$ lysozyme, $1.5 \mathrm{mg} / \mathrm{ml}$ proteinase $\mathrm{K}, 20 \mu \mathrm{g} / \mathrm{ml}$ RNase), mixed gently and incubated at $37^{\circ} \mathrm{C}$ for $10 \mathrm{~min}$. An equal volume of $1.2 \%$ molten SeaKem Gold agarose (FMC BioProducts, Rockland, Maine) containing 1\% sodium dodecyl sulfate was added, the mixtures were poured in duplicate into $2-\mathrm{cm}$ by $1-\mathrm{cm}$ by $1.5-\mathrm{mm}$ reusable plug molds (Bio-Rad Laboratories, Hercules, CA) and allowed to solidify at room temperature for $10 \mathrm{~min}$. The duplicate plugs were added to a tube containing $1.8 \mathrm{~mL}$ of proteolysis solution [0.44 M EDTA ( $\mathrm{pH}$ 8.0), 1\% sarcosyl, $400 \mu \mathrm{g} / \mathrm{ml}$ of proteinase $\mathrm{K}]$ and incubated with constant agitation at $300 \mathrm{rpm}$ for $2 \mathrm{~h}$ at $55^{\circ} \mathrm{C}$. Plugs were washed 3 times for $10 \mathrm{~min}$ each in $\mathrm{H}_{2} \mathrm{O}(1.8 \mathrm{~mL})$, followed by 3 times for $10 \mathrm{~min}$ in $\mathrm{TE}(1.8 \mathrm{~mL})$ in a thermomixer set at $50^{\circ} \mathrm{C}$ and $300 \mathrm{rpm}$. One plug was cut in three equal slices latitudinally and two of the gel slices were pre-incubated in $200 \mu \mathrm{L}$ of $1 \mathrm{X}$ restriction enzyme buffer for $15 \mathrm{~min}$ at $30^{\circ} \mathrm{C}$. DNA in the plugs was restricted with 50 units of SmaI in a $200 \mu \mathrm{L}$ reaction mixture for $3 \mathrm{~h}$ at $25^{\circ} \mathrm{C}$. As a reference standard $\mathrm{XbaI}$ digested Salmonella serotype Braenderup (H9812) plugs were prepared as previously described (Klima et al., 2011).

The digested plugs were embedded in 1\% SeaKem Gold lowmelting temperature agarose (Lonza Canada, Inc., Shawinigan, QC) that was dissolved in $0.5 \times$ TBE $(45 \mathrm{mM}$ Tris, $45 \mathrm{mM}$ boric acid, $1 \mathrm{mM}$ EDTA, pH 8.0). Prior to incorporation into the gel, digested plugs were incubated with $200 \mu \mathrm{l}$ of $0.5 \times \mathrm{TBE}$ at room temperature for $20 \mathrm{~min}$. The digested DNA were separated by PFGE using a CHEF DRII device (Bio-Rad Laboratories Ltd., Mississauga, $\mathrm{ON}$, Canada), at $12^{\circ} \mathrm{C}$. The voltage was maintained at $6 \mathrm{~V} / \mathrm{cm}$ for a total of $21 \mathrm{~h}$ with switch times of $4-40 \mathrm{~s}$ for initial $12.5 \mathrm{~h}$ followed by switch times of $1.5-6$ for $8.5 \mathrm{~h}$. The gels were run in $0.5 \times$ TBE buffer containing $0.45 \mathrm{mM}$ thiourea. After electrophoresis, gels were stained with ethidium bromide $(1 \mu \mathrm{g} / \mathrm{ml})$ in distilled water for $20 \mathrm{~min}$ followed by three $20 \mathrm{~min}$ washes with distilled water. Gels were photographed with an AlphaImager gel documentation system (Alpha Innotech Corp., St. Leandro, CA). Fragment analysis was performed with BioNumerics V5.1 software (Applied Maths Inc., Austin, TX).

\section{IDENTIFICATION OF MACROLIDE RESISTANCE DETERMINANTS}

Erythromycin-resistant isolates were evaluated for the presence of the commonly found macrolide resistance determinants erm(A), 
$\operatorname{erm}(\mathrm{B}), \operatorname{erm}(\mathrm{C}), \operatorname{erm}(\mathrm{F}), \operatorname{erm}(\mathrm{T}), \operatorname{erm}(\mathrm{X}), \operatorname{mef}(\mathrm{A})$ (http://faculty. washington.edu/marilynr/) by PCR analyses. For generating PCR template, a single bacterial colony was suspended in $50 \mu \mathrm{L}$ of TE (10 mM Tris.HCl pH 8.0, $1 \mathrm{mM}$ EDTA pH 8.0) and incubated at $95^{\circ} \mathrm{C}$ for $5 \mathrm{~min}$ followed by centrifugation at $10,000 \times \mathrm{g}$ for $5 \mathrm{~min}$. Supernatant $(2 \mu \mathrm{L})$ was used as template in a $20 \mu \mathrm{L}$ volume PCR reaction mixture using PCR primers and reaction conditions as described elsewhere (Chen et al., 2007; Szczepanowski et al., 2009). The commercially available HotStarTaq Plus Master Mix Kit (Qiagen Canada, Inc., Mississauga, ON, Canada) was used according to manufacturer's instructions. Plasmids containing corresponding gene fragments previously cloned in our laboratory were used as positive controls. Select PCR fragments amplified from erythromycin resistant isolates originating from the present study were verified by DNA sequencing.

\section{STATISTICAL ANALYSIS}

Data were analyzed using commercially available statistical analysis software (SAS System for Windows, release 9.1.3, SAS Institute, Cary, NC). Prevalence of $M$. haemolytica and erythromycin resistance in enterococci were analyzed using logistic methodology within the GLIMMIX procedure of SAS, with treatment in the model and day of sampling treated as a repeated measure. Model adjusted means (LS means back-transformed to original scale) and standard errors were reported and used to estimate the efficacy of the antibiotic treatments for controlling M. haemolytica. For all tests, the level of significance was set at $P<0.05$.

\section{ETHICS STATEMENT}

Experiments with beef steers were conducted according to the Canadian Council on Animal Care (CCAC) guidelines. The studies were approved by the institutional Animal Care Committee (ACC), Lethbridge Research Centre, Agriculture and Agri-Food Canada, under protocol number 1111. Antibiotics were administered or fed at levels approved by the Canadian Bureau of Veterinary Drugs and recommended by the manufacturer and used in accordance with industry practices.

\section{RESULTS}

\section{Mannheimia haemolytica CHARACTERIZATION}

A total of 274 suspect $M$. haemolytica isolates were obtained over the duration of the study of which 260 were confirmed by multiplex PCR assay (Alexander et al., 2008). Isolates were obtained from 29 out of the 40 steers used in the experiment. All of the confirmed $M$. haemolytica isolates were serotyped and 160 (1-3 isolates per Mannheimia positive animal per sampling event) were tested for antimicrobial susceptibility using the disk diffusion assay, and 65 (one isolate belonging to each of the M. haemolytica positive animals for each sampling event) were subjected to PFGE.

Serotyping revealed that $89 \%(232 / 260)$ of the M. haemolytica isolates that originated from $93 \%(27 / 29)$ of the positive animals were serotype 1 , whereas $8.4 \%(22 / 260)$ of the isolates, all of which originated from a single steer were serotype 2 . Two percent $(5 / 260)$ of the isolates were identified as serotype 6 , all of which were obtained from a single steer on the 28th day post treatment. Two main clusters were identified by PFGE analysis, cluster A consisted primarily of serotype 1 isolates with only a single serotype 6 isolate, whereas cluster B was comprised of serotype 2 isolates (Figure 2). Two sub-clusters, A1 and A2 were observed within cluster A; A1 solely comprising serotype 1 isolates and A2 consisting of a mixture of serotype 1 and 6 (Figure 2).

The prevalence of $M$. haemolytica dropped substantially from steers that were injected with tilmicosin or tulathromycin as compared to levels prior to treatment (Figure 3A). Compared to the control, the number of steers harboring M. haemolytica was reduced $(P<0.05)$ by systemic treatment with either tilmicosin or tulathromycin over the post treatment sampling period (days 7-28). Compared to the in-feed tylosin, tilmicosin and tulathromycin also resulted in a reduction $(P<0.05)$ in number of cattle positive for M. haemolytica (64 and 42\%, respectively) (Figure 3B). In disk diffusion assays, $M$. haemolytica isolates cultured without erythromycin on primary isolation were all sensitive to amoxicillin/clavulanic acid, ampicillin, ceftiofur, danofloxacin, erythromycin, florfenicol, gentamicin, oxytetracycline, spectinomycin, trimethoprim/sulfamethoxazole, tilmicosin, and tulathromycin.

\section{CHARACTERIZATION OF BACTERIA CO-ISOLATED WITH M. haemolytica}

The non-Mannheimia bacterial colonies originating from nasopharyngeal samples cultured on BAC or BAC+Ery agar plates were divided into 11 morphological groups (Table 2). The 16S rRNA gene sequences from 165 select isolates with 5-15 isolates representing each morphology group were subsequently analyzed for genus/species identification through alignments using "seqmatch" (http://rdp.cme.msu.edu/index.jsp) or BLAST (http://blast.ncbi.nlm.nih.gov/). The morphotypes were found to be very consistent with $16 \mathrm{~S}$ rDNA sequence based bacterial identification and therefore were used to define the identity of collected isolates. One representative of each morphotype per sampling event was used to determine bacterial prevalence. Along with $M$. haemolytica (13\%), other bacteria found in abundance included Pasteurella multocida (25\%), Staphylococcus spp. (25\%), Acinetobacter spp. (9\%), E. coli/Shigella group (8\%), and Bacillus licheniformis (7\%) (Figure 4). Among the Staphylococcus spp., S. epidermidis, S. pasteuri, and S. cohnii were abundant and collectively constituted $20 \%$ of isolated nasopharyngeal bacterial species, with $S$. sciuri only occasionally isolated. These Staphylococcus species had indistinguishable colony morphologies and thus collectively constituted one morphological group (Table 2). Staphylococcus chromogenes was placed in a separate morphological group due to its distinct yellow color and it constituted $5 \%$ of isolated nasopharyngeal bacterial species. Other species such as streptococci, Macrococcus casseolyticus and Bacillus spp. including B. clausii and B. pumilus were less abundant (Figure 4). However, collectively and irrespective of morphotypes, Bacillus spp. constituted $\sim 14 \%$ of isolated bacteria.

Erythromycin resistance was found in all isolated bacterial species except $M$. haemolytica, $P$. multocida and other less frequently isolated bacteria (Table 2). Of the seven macrolide resistance genes tested by PCR, the $\operatorname{erm}(\mathrm{C})$ was predominantly found in Staphylococcus spp. (Table 2). With regard to 


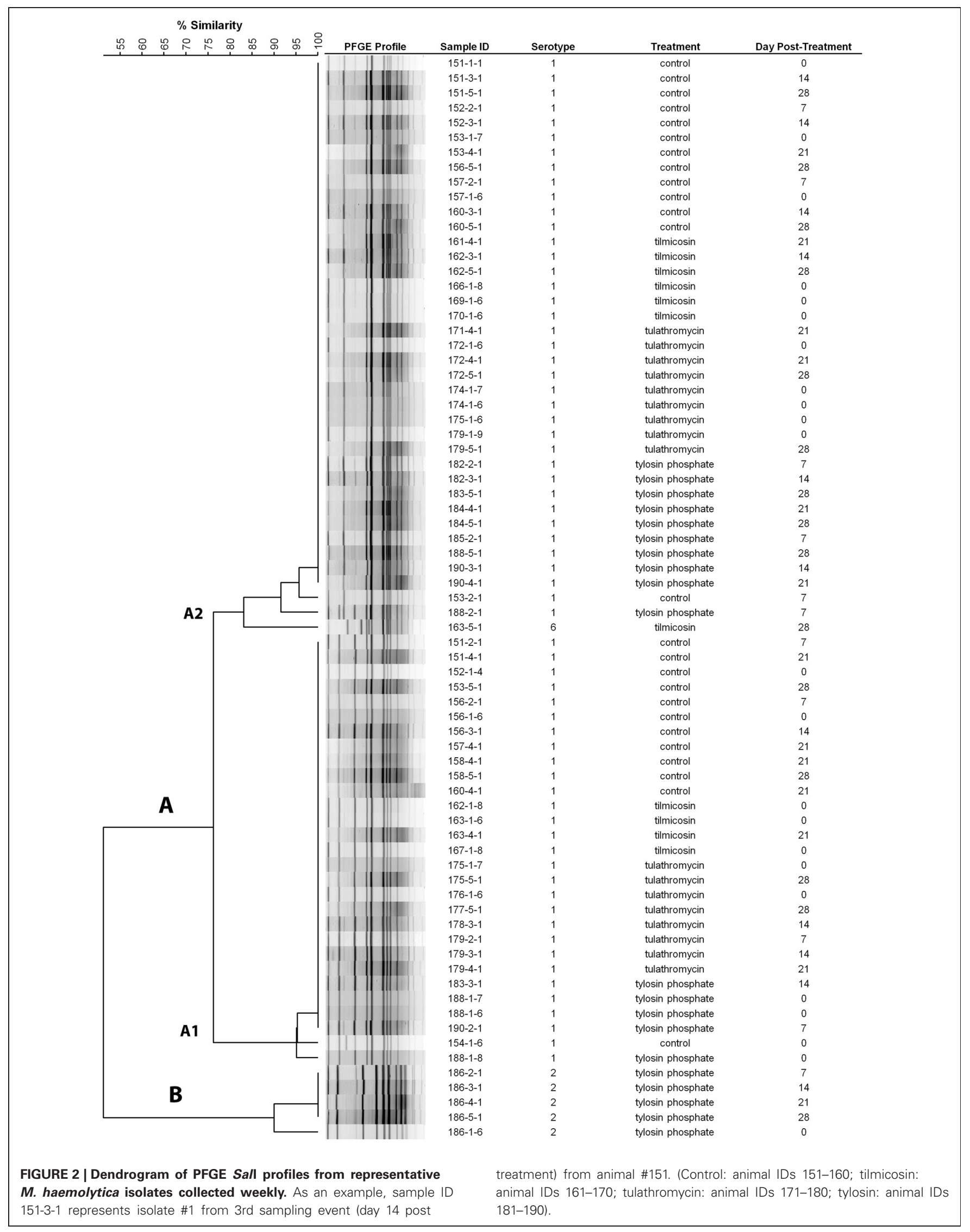




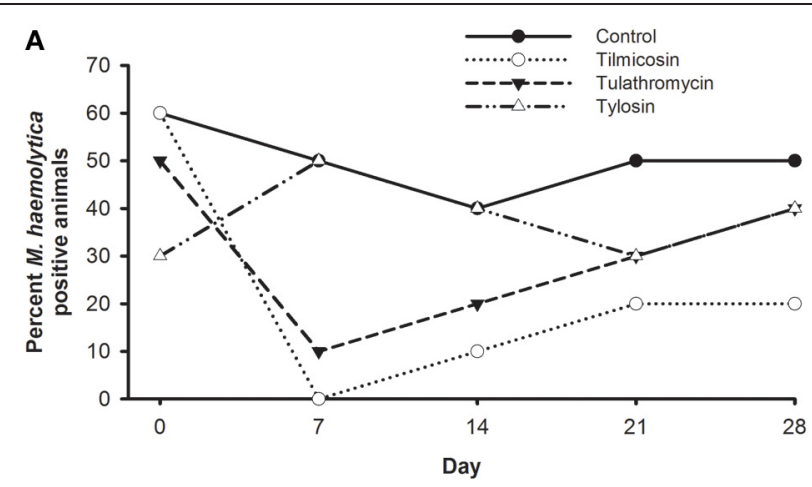

B

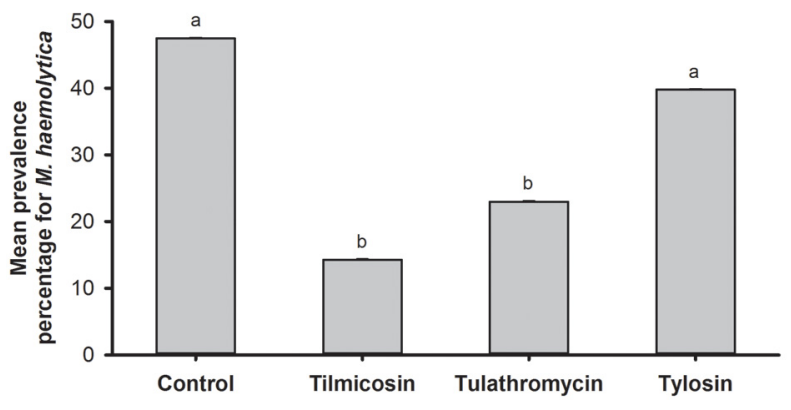

FIGURE 3 | (A) Percentage of animals positive for $M$. haemolytica for each of the five sampling events over 28 days study period. (B) Mean percentage of $M$. haemolytica prevalence in animals over the entire study period. Means with different superscripts differ $(P<0.05)$. other erythromycin-resistant isolates, no resistance determinants matching any of the seven PCR primer pairs were amplified and therefore were considered as "not detected".

\section{EVALUATION OF ENTEROCOCCI PRE- AND POST-MACROLIDE-TREATMENT}

Enterococci were isolated from all 40 animals (control and treatment groups) on arrival (day 0), and weekly thereafter for 4 weeks (day 7, 14, 21, and 28). Enterococci colonies obtained on BEA and BEA+Ery plates were enumerated and the proportion of erythromycin resistant colonies was calculated for each sample (Figure 5). Compared to the control group, antibiotic treatment groups were 76 times more likely $(P<0.02)$ to have erythromycin resistant enterococci over the study period (days 7-28). Similarly, for all treatment groups, post-treatment samples from the entire study period were 66 times more likely to have erythromycin resistant enterococci $(P<0.001)$ when compared to pre-treatment (day 0) samples. No significant differences in the incidence of erythromycin resistance were observed between injectable (tilmicosin and tulathromycin) and in-feed (tylosin) macrolides.

Speciation of 130 of the enterococci isolates collected from day 0,7 , or 28 revealed that all were Enterococcus hirae with the exception of two which were Enterococcus casseliflavus. Fifty select isolates of erythromycin resistant enterococci from day 0 and day 7 sampling events were used for the identification of erythromycin resistance determinants. Of the seven macrolide resistance genes investigated via PCR only the erm(B) gene was identified in enterococci isolates.

Table 2 | Bacteria co-isolated with M. haemolytica.

\begin{tabular}{|c|c|c|c|c|}
\hline Morphotypes & Morphology on BAC-agar plates & $\begin{array}{l}\text { Species identification based on } 16 S \\
\text { rDNA sequencing }\end{array}$ & Ery resistance & $\begin{array}{l}\text { Resistance } \\
\text { determinant(s) }\end{array}$ \\
\hline $\mathrm{Mh}$ & Small, glossy, grey, beta-haemolytic & Mannheimia haemolytica ${ }^{a}$ & - & - \\
\hline 2 & Large, mucoid, semi-transparent, grey-white & Pasteurella multocida & - & - \\
\hline 4 & $\begin{array}{l}\text { Medium/large, wrinkly, crusty, fluid-filled, } \\
\text { beta-haemolytic }\end{array}$ & Bacillus licheniformis & + & ND \\
\hline 5 & $\begin{array}{l}\text { Medium/large, glossy, grey-white, mostly } \\
\text { beta-haemolytic }\end{array}$ & Escherichia coli/Shigella & + & - \\
\hline 6 & Medium/large, rough edges, flat, granular & Bacillus clausii/Bacillus spp. & + & ND \\
\hline 10 & $\begin{array}{l}\text { Medium, yellowish, concentric circles, very } \\
\text { haemolytic, greenish }\end{array}$ & Bacillus pumilus & NA & ND \\
\hline U & Unique morphologies found occasionally & $\begin{array}{l}\text { Klebsiella, Neisseria spp., Paenibacillus } \\
\text { spp., uncultured bacteria }\end{array}$ & NA & ND \\
\hline
\end{tabular}

${ }^{a}$ Also confirmed by multiplex PCR assay (Alexander et al., 2008); NA, not available, as those morphology groups were less commonly found on BAC plates and not found on BAC+Ery plates; ND, not determined (no positives detected in PCRs with any of the tested macrolide primer sets, see Materials and Methods). 


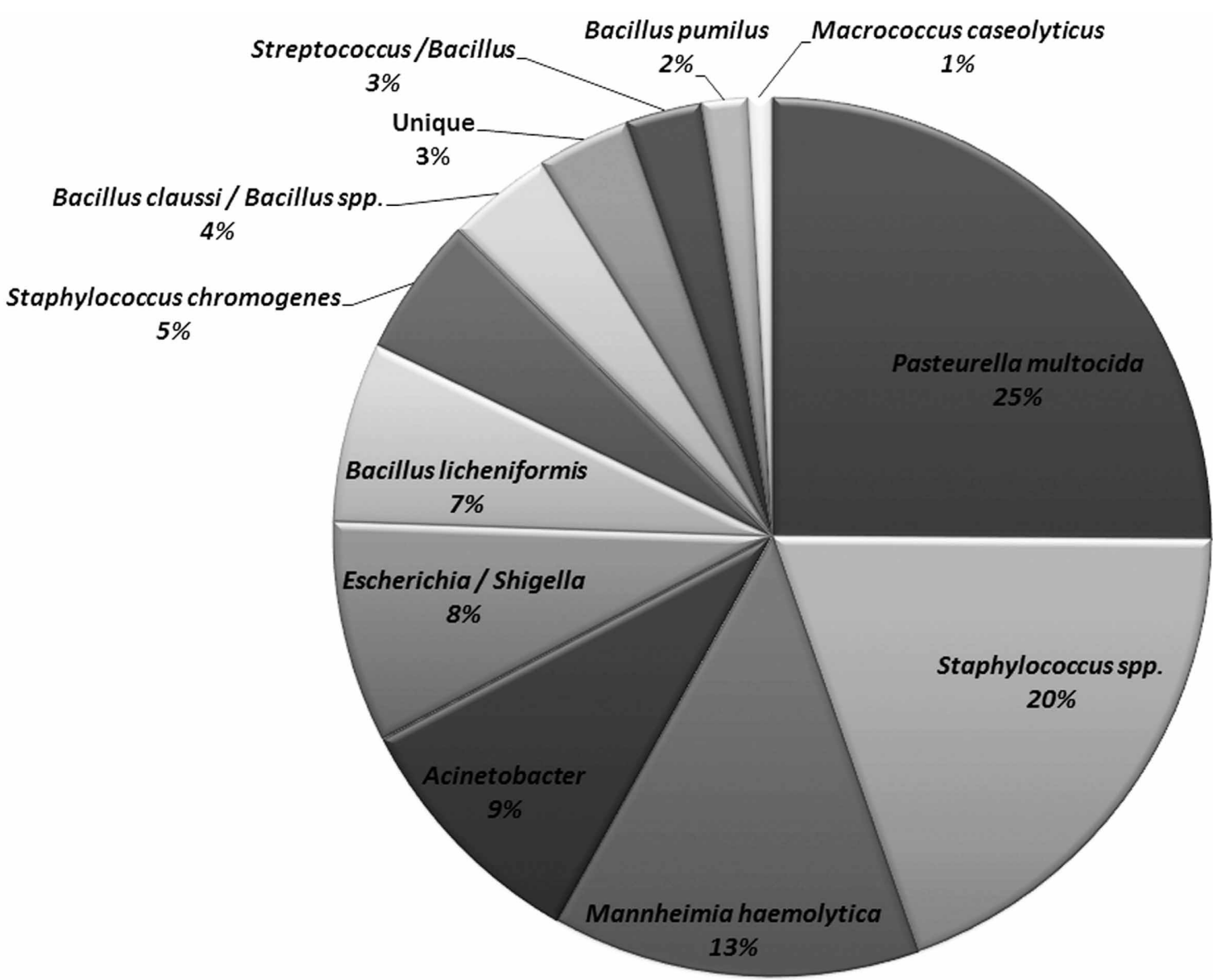

FIGURE 4 | Relative abundance of bacitracin resistant bacterial species isolated from nasopharynx over 28-days sampling period. One representative of each morphology per animal per sampling event were used to determine bacterial species prevalence $(n=466)$.

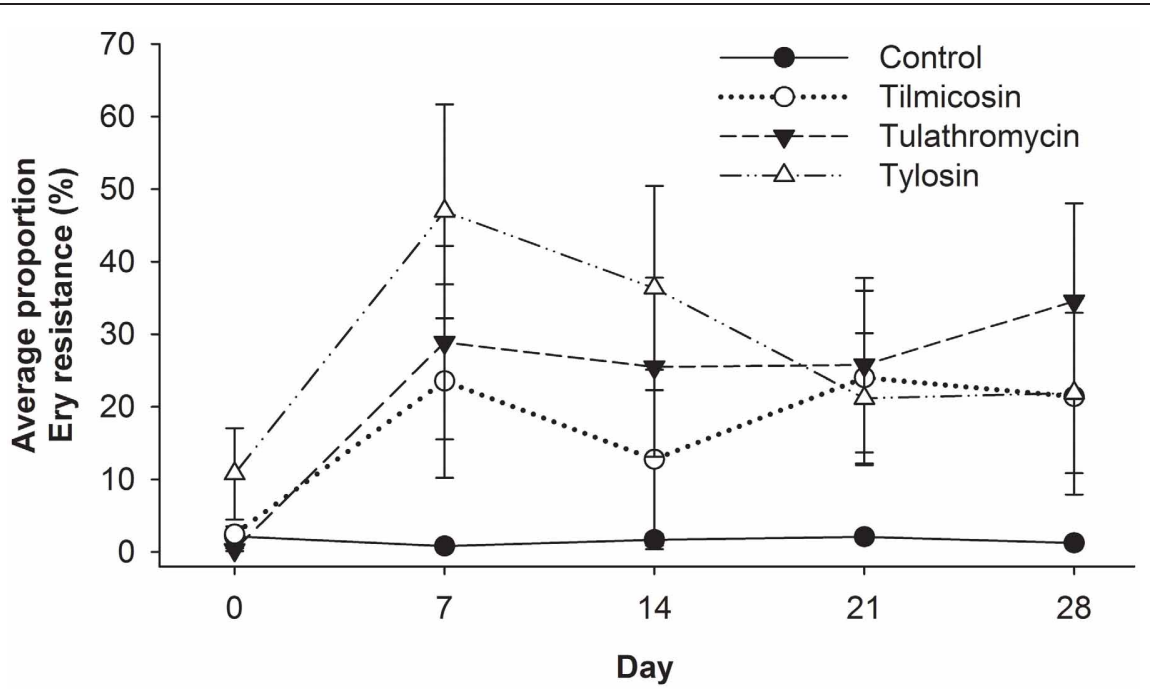

FIGURE 5 | Proportion of erythromycin-resistant faecal enterococci isolates for each of the five sampling events over $\mathbf{2 8}$ days study period, with day 0 samples collected prior to antibiotic treatment. From day 7 onward, Control isolates had less resistance detected $(P<0.05)$ than antibiotic treated groups, while resistance noted with injectable macrolides (tilimicosin and tulathormycin) did not differ from that cattle fed tylosin. 
A representative 36 erythromycin resistant enterococci from 12 select animals from three sampling events (day 0, 7, and 28) were subject to PFGE and produced three closely related clusters (>85\% similarity) (Figure 6). In eight of the twelve animals the PFGE profiles from the three sampling events had $>90 \%$ similarity indicating that erythromycin resistant enterococci likely consisted of a persistent clonal population.

\section{DISCUSSION}

The objective of this study was to evaluate and compare the effect of in-feed subtherapeutic and injectable therapeutic administration of macrolides on antimicrobial susceptibility of indicator bacteria from the digestive and respiratory tract of feedlot cattle. For this purpose we selected faecal enterococci and M. haemolytica as our indicator bacteria for the digestive and respiratory tract, respectively. Injectable macrolide antimicrobials such as tilmicosin and tulathromycin are commonly used at therapeutic levels in beef cattle production to prevent and treat BRD. The macrolide, tylosin is frequently administered in-feed at subtherapeutic doses for improving feed efficiency and for the reduction of liver abscesses caused by Fusobacterium necrophorum and Actinomyces pyogenes (www.merckvetmanual.com). The subtherapeutic administration of antibiotics has been hypothesized to promote resistance development as bacteria are exposed to sublethal concentrations of antibiotic for prolonged periods of time. Consequently, the subtherapeutic administration of antibiotics in animal feeds for growth promotion has been proposed as a serious public health concern (Aarestrup and Wegener, 1999; Wegener et al., 1999; McEwen and Fedorka-Cray, 2002). Over the last 6-10 years the minimum inhibitory concentrations (MICs) of tilmicosin and tulathromycin towards M. haemolytica have markedly increased (Portis et al., 2012), questioning the continued effectiveness of these antibiotics against the etiological agents of BRD. Furthermore, M. haemolytica could serve as a reservoir of macrolide resistance genes, potentially disseminating them to other respiratory pathogens.

Deep nasopharyngeal swabs were taken to isolate M. haemolytica as this procedure is quick, simple and relatively non-invasive. In our study, a single systemic administration of therapeutic levels of either tilmicosin or tulathromycin was effective in lowering M. haemolytica in the nasopharynx of steers (Figures 3A,B). According to the manufacturer, (ELANCO Animal Health, Guelph, On, Canada, www.elanco.ca) injecting cattle with $10 \mathrm{mg}$ of tilmicosin $/ \mathrm{kg}$ of body weight results in lung concentrations exceeding the $\operatorname{MIC}(3.12 \mu \mathrm{g} / \mathrm{mL})$ for $M$. haemolytica for at least 3 days, eliminating it from the respiratory tract for up to 6 days (Frank et al., 2000). Tulathromycin is believed to accumulate in neutrophils and alveolar macrophages (Siegel et al., 2004; Cox et al., 2010), with peak lung levels of $4.1 \mu \mathrm{g} / \mathrm{mL}$ occurring in cattle $24 \mathrm{~h}$ after a single injection and concentrations remaining above the MIC for $M$. haemolytica $(2.0 \mu \mathrm{g} / \mathrm{mL})$ for 10 days (www.pfizer.ca). Our data demonstrated that 7 days postinjection, $M$. haemolytica was detected in only one steer treated with tulathromycin and none of the steers treated with tilimicosin, whereas $60 \%$ of steers were positive for this bacterium upon arrival (day 0 ). This suggests that $M$. haemolytica in newly arrived cattle were not macrolide resistant, an observation supported by our inability to isolate erythromycin resistant $M$. haemolytica and likely a reflection of the fact that these cattle had no previous exposure to macrolides.

In contrast to injectable macrolides, tylosin had no effect on the number of $M$. haemolytica in steers administered this antibiotic in feed as compared to cattle that received no antibiotics (Figures 3A,B). This observation likely reflects differences in the method and concentration of the antibiotic administered and the sensitivity of $M$. haemolytica to tylosin. Tylosin is not effective at penetrating the outer membrane of Gram-negative bacteria and as a result its MIC $(64 \mu \mathrm{g} / \mathrm{mL})$ against $M$. haemolytica is much higher than either tilimicosin or tulathromycin (Andersen et al., 2012). Tylosin is known to be widely distributed in body fluids and tissues, but comparative pharmacokinetics of its distribution in the digestive tract relative to the respiratory tract when it is administered in feed are poorly characterized (Lewicki, 2006).

Mannheimia haemolytica isolated from animals belonging to control and all three macrolide treatment groups throughout the course of study were found to be susceptible to all tested macrolides indicating that both therapeutic and subtherapeutic administration did not contribute to macrolide resistance in M. haemolytica during the study. Mannheimia haemolytica isolated in the present study were also susceptible to all other antibiotics tested (Table 2). While tilmicosin and tulathromycin are generally effective against $M$. haemolytica, a few isolates originating from Germany, Japan and United States have shown resistance to these antibiotics (Katsuda et al., 2009; Watts and Sweeney, 2010; Michael et al., 2012). An integrative conjugative element (ICE) has been identified in P. multocida that exhibits high similarity to ICEs in P. multocida 36950, Histophilus somni 23364 and an ICE fragment within the incomplete M. haemolytica PHL23 genome (Michael et al., 2012). This is a matter of concern as $P$. multocida, M. haemolytica, and $H$. somni often share the same ecological niche in the bovine respiratory tract and exchange of this ICE element could lead to macrolide resistance in these BRD pathogens as transfer of this element among $P$. multocida, M. haemolytica, and E. coli has been demonstrated in the laboratory (Dabo et al., 2007; Watts and Sweeney, 2010).

The majority of $M$. haemolytica isolates collected from asymptomatic animals in this study were serotype 1 (Figure 2). The PFGE profiles of serotype 1 and 6 isolates clustered together with a $\sim 83 \%$ relatedness, a relationship observed previously for these serotypes (Klima et al., 2011). The predominance of a single serotype in the majority of steers is likely a reflection of sourcing them from the same isolated ranch in southern Alberta and transporting them directly to the Lethbridge Research Centre. This arrangement was necessary to ensure that steers had no exposure to antibiotics prior to arrival. Serotype 1 has frequently been linked to clinical disease and both serotypes 1 and 6 are often isolated from cattle with BRD (Zecchinon et al., 2005). However, none of the steers in the present study exhibited clinical BRD. The BRD complex consists of a bacteria (M. haemolytica, Pasteurella multocida, Histophulus somni, Mycoplasma bovis) and viruses (Bovine Viral Diarrhea, Infectious Bovine Rhinotracheitis, Bovine Respiratory Synctial Virus, Parainfluenza Type-3 Virus) which together supress innate immune responses and cause lung damage (Fulton, 2009; Pardon 


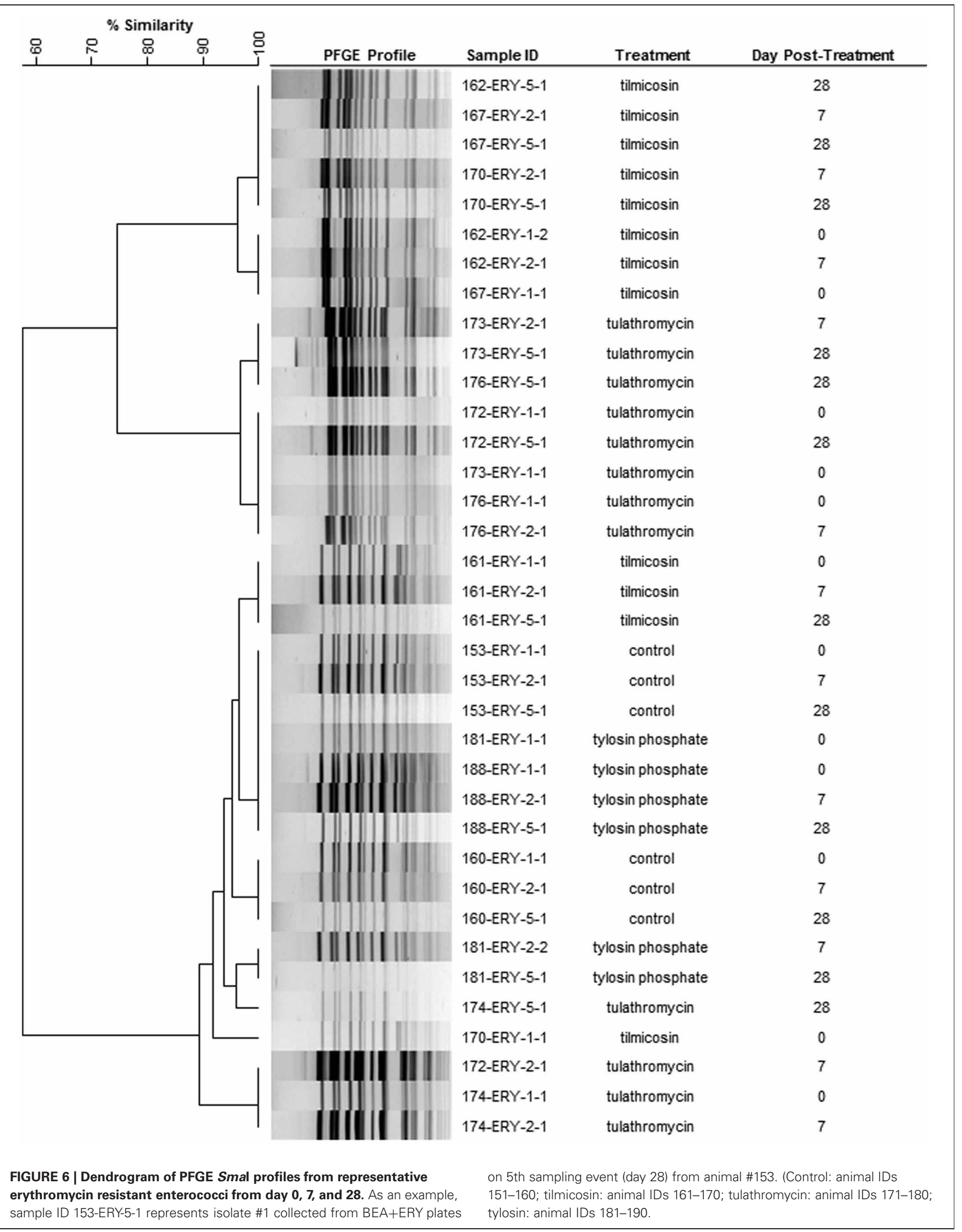


et al., 2011). It seems likely that in this study the steers lacked the infectious complex necessary for the development of BRD.

Pasturella multocida was the most ubiquitous bacterium isolated from the nasopharynx of steers and in contrast to M. haemolytica, prevalence of this bacterium was similar in pre- and post-treatment groups. However, none of the isolated P. multocida exhibited resistance to erythromycin. As $P$. multocida were not enumerated, it is possible that macrolides reduced the population of this bacterium. After P. multocida, Staphylococcus spp. was most abundant with a relative abundances of $S$. epidermidis $>$ S. pasteuri $>$ S. cohnii $>$ S. sciuri $>$ S. saprophyticus. Staphylococci are ubiquitous Gram-positive bacteria and are common in the microflora of skin and mucosal surfaces. Currently, there are 31 species recognized in the genus Staphylococcus and about half of these are indigenous to humans (Kloos and Bannerman, 1994). The role of some species, such as S. epidermidis, S. saprophyticus, S. Pasteuri and S. cohni in human disease has been well documented (Piette and Verschraegen, 2008; Savini et al., 2009). Consistent with previous studies (Aarestrup et al., 2000a; Simeoni et al., 2008), the majority of the erythromycin resistant Staphylococcus spp. harbored $\operatorname{erm}(\mathrm{C})$.

Thirteen percent of the isolated nasopharyngeal bacteria were M. haemolytica followed by Acinetobacter, Enterobacteriaceae (Esherichia spp., Shigella spp.) and Bacillus spp. including $B$. licheniformis and B. clausii. Most of these bacteria are recognized as part of normal flora of the skin, oropharynx and perineum of healthy individuals. While erythromycin resistance was found in the majority of isolated nasopharyngeal bacteria, macrolide determinants could only be detected in the Staphylococcus group. The primers we used to detect seven macrolide resistance genes would not be expected to capture all of the genes potentially conferring resistance. For example, primers for erythromycin resistance genes erm(D) and erm(34) previously characterized from $B$. licheniformis and B. clausii, respectively (Israeli-Reches et al., 1984; Bozdogan et al., 2004) were not included in our panel. Although we observed no increase in the diversity of erythromycin resistant nasopharyngeal bacteria in our study, determinants in those bacteria that possessed them could be disseminated into the broader environment.

Escherichia coli are commonly used as faecal indicator bacteria to assess AMR, but we chose enterococci as E. coli are intrinsically resistant to macrolides (Mao and Putterman, 1968). Enterococci are common inhabitants of the normal gut flora of both livestock and humans (Yost et al., 2011). Outside of their normal habitat, enterococci are viewed as pathogens and may present a public health concern as they can be transmitted to humans from other hosts or by ingestion of contaminated food or water (Heuer et al., 2006; Marshall and Levy, 2011). Enterococci, in particular E. faecalis and E. faecium are recognized as prevalent nosocomial pathogens (Fisher and Phillips, 2009; van Schaik and Willems, 2010) with many isolates being resistant to multiple antibiotics and capable of exchanging DNA with other bacteria (SchjØrring and Krogfelt, 2011). In the present study we did not isolate either E. faecalis or E. faecium, with E. hirae being the predominant species isolated from cattle, a species infrequently associated with hospital infections.
The present study revealed a significant increase in the proportion of erythromycin resistant enterococci following macrolide treatment regardless of the method of administration (Figure 5). Oral administration of tylosin was expected to have a direct impact on the enterococci population of the gut, but the occurrence of erythromycin resistant enterococci in cattle administered injectable macrolides was equally marked. Studies submitted to the Food and Drug Administration's Center for Veterinary Medicine (FDA/CVM) showed that with a single subcutaneous dose of tilmicosin to cattle, $24 \%$ was recovered in the urine and $68 \%$ in the feces, whereas with tulathromycin, $50 \%$ was recovered in the feces with $90 \%$ of this being in its original form. It has been proposed that tulathromycin losses activity at $\mathrm{pH} \leq 7.0$, (Food and Drug Administration's Center for Veterinary, 2013), but considering that the $\mathrm{pH}$ in intestinal digesta and in feces is usually neutral or acidic (Allison et al., 1979; Canh et al., 1997), our results would suggest that this antibiotic selected for resistant enterococci within the intestinal tract. It is possible that the forage rich diet used in our study resulted in intestinal contents having, a $\mathrm{pH}$ above 7.0, allowing the concentration of tulathromycin in digesta to exceed the MIC of enterococci. High forage diets in cattle are known to increase colonic $\mathrm{pH}$ to ranges between 7.4 and 8.0 (Scott et al., 2000; Loy et al., 2001), but results could be quite different on high grain diets where the $\mathrm{pH}$ of digesta is considerably lower.

Similar PFGE profiles were observed for erythromycin resistant enterococci from both pre- and post-treatment samples (Figure 6), suggesting that regardless of the method of administration, macrolides selected for erythromycin resistant enterococci that were already in the digestive tract. Selection for resistant enterococci combined with a reduction in susceptible enterococci significantly increased the presence of erythromycin resistant Enterococcus spp. within the digestive tract. This observation is of interest considering that the cattle used in this study originated from a very isolated ranch and never had prior direct exposure to macrolides. It would be interesting to examine the persistence of this resistant population for a prolonged period of time to understand population dynamics and to investigate if the metabolic burden/cost of antibiotic resistance genes in the absence of macrolides leads to a decline in resistance within the enterococci population over time. As is typical in industry, cattle in this study were treated with injectable macrolides early in the feeding period. Considering that they would have been fed for an additional 200 days prior to slaughter, loss of resistant enterococci from the intestinal tract at later points in the feeding period is a distinct possibility. However, resistant enterococci may persist in cattle fed tylosin as this antibiotic is often administered for a longer duration of the feeding period.

All of the isolated erythromycin resistant enterococci contained erm(B), a gene coding for rRNA adenine N-6methyltransferase, which methylates the A2058 position of $23 \mathrm{~S}$ rRNA. Macrolide resistance in enterococci isolates from humans and animal sources in Europe has been well documented (Jensen et al., 1999; Aarestrup et al., 2001). Occurrence of macrolide resistance in enterococci originating from swine is thought to stem from the subtherapeutic use of tylosin (Jackson et al., 2004). The co-existence of macrolide resistance genes with other 
antibiotic resistance genes has also been observed, most notably a link between resistance to macrolides and vancomycin (Aarestrup et al., 2000b), attributable to erm(B) and the vanA gene occurring in close proximity on the same plasmid. The increased occurrence of both erm and tet (tetracycline resistance) genes in faecal microbial communities from beef cattle fed subtherapeutic levels of tylosin has also been identified (Chen et al., 2008). Linkage of determinants for $\mathrm{MLS}_{\mathrm{B}}$ and chloramphenicol resistance has also been found on a single conjugative plasmid in E. faecium and dissemination of this cluster among streptogramin-resistant enterococci occurs (Werner et al., 2000). Resistance to MLS $_{B}$ antibiotics in Gram-positive cocci colonizing humans is now recognized to be a serious problem, negatively affecting clinical outcomes (Lim et al., 2002; DiPersio and DiPersio, 2006).

Regardless of the hypothesized prospects of subtherapeutic administration of antimicrobials contributing towards AMR development, there is limited and conflicting data as to the extent that subtherapeutic vs. therapeutic drug administration contributes to livestock mediated antimicrobial resistance. Studies have shown that subtherapeutic administration of tylosin had no impact on the prevalence of erythromycin resistant Campylobacter in feedlot cattle (Inglis et al., 2005), whereas with broiler chickens the frequency of macrolide resistant Campylobacter in cecal contents was increased with subtherapeutic vs. therapeutic doses of tylosin (Ladely et al., 2007). These discrepancies may reflect species-specific (cattle vs. chicken) differences in gastrointestinal physiology and diet. Others have found that short-term therapeutic use of chlortetracycline in the diet was no less likely to select for resistant Salmonella populations than long-term subtherapeutic use (Kobland et al., 1987). In-feed and subcutaneous administration of oxytetracycline were also equally responsible for increasing the proportion of feedlot cattle excreting tetracycline resistant E. coli in faeces (Checkley et al., 2010).

\section{REFERENCES}

Aarestrup, F. M., Agersł, Y., Ahrens, P., Jłrgensen, J. C., Madsen, M., and Jensen, L. B. (2000a). Antimicrobial susceptibility and presence of resistance genes in staphylococci from poultry. Vet. Microbiol. 74, 353-364.

Aarestrup, F. M., Kruse, H., Tast, E., Hammerum, A. M., and Jensen, L. B. (2000b). Associations between the use of antimicrobial agents for growth promotion and the occurrence of resistance among Enterococcus faecium from broilers and pigs in Denmark, Finland, and Norway. Microb. Drug Resist. 6, 63-70.

Aarestrup, F. M., and Wegener, H. C. (1999). The effects of antibiotic usage in food animals on the development of antimicrobial resistance of importance for humans in Campylobacter and Escherichia coli. Microbes. Infect. 1, 639-644.
Aarestrup, F. M. A., Seyfarth, M., Emborg, H. D., Pedersen, K., Hendriksen, R. S., and Bager, F. (2001). Effect of abolishment of the use of antimicrobial agents for growth promotion on occurrence of antimicrobial resistance in fecal enterococci from food animals in Denmark. Antimicrob. Agents Chemother. 45, 2054-2059.

Addah, W., Baah, J., Groenewegen, P., Okine, E. K., and McAllister, T. A. (2011). Comparison of the fermentation characteristics, aerobic stability and nutritive value of barley and corn silages ensiled with or without a mixed bacterial inoculant. Can. J. Anim. Sci. 91, 133-146.

Alexander, T. W., Cook, S. R., Yanke, L. J., Booker, C. W., Morley, P. S., Read, R. R., et al. (2008). A multiplex polymerase chain reaction assay for the identification of Mannheimia haemolytica, Mannheimia glucosida

The present study offers a comparison of subtherapeutic and therapeutic drug administration with regards to the prevalence of resistance among bacteria from two independent locations in cattle. In conclusion, the injectable macrolides had impact on both respiratory and enteric microbes whereas orally administered macrolides only influenced enteric bacteria. Therapeutic levels of tilmicosin and tulathromycin were effective in lowering nasopharyngeal $M$. haemolytica, whereas the in-feed levels of tylosin had no effect on the prevalence of this bacterium. $M$. haemolytica isolates from control and macrolide treated animals were found to be susceptible to macrolides as well as other antibiotics tested. The lack of AMR in M. haemolytica may be attributed to the possible absence of AMR determinants in Mannheimia as well as other closely related bacteria such as P. multocida. Erythromycin resistance was detected in nasopharyngeal bacteria co-isolated with $M$. haemolytica, regardless of the treatment group. All three macrolides increased the occurrence of erythromycin resistance Enterococcus spp. within the intestinal tract of cattle, but the species identified were not those most frequently linked to nosocomial infections in humans. To our knowledge this is the first report on increased occurrence of macrolide resistance in enterococci after systemic macrolide usage in cattle. It would be interesting to monitor the post-treatment AMR resistance over a period of weeks to months beyond treatment to determine if these macrolide-resistant enterococci continue to persist within the faecal bacterial populations of cattle.

\section{ACKNOWLEDGMENTS}

This study was conducted with funding from SAGES program of Agriculture and Agri-Food Canada in partnership with the University of Calgary. We thank Ruth Barbieri, Lorna Selinger, Shea Brennan, Wendi Smart, and animal handling staff for their technical assistance.

and Mannheimia ruminalis. Vet. Microbiol. 130, 165-175.

Allison, M. J., Robinson, I. M., Bucklin, J. A., and Booth, G. D. (1979). Comparison of bacterial populations of the pig cecum and colon based upon enumeration with specific energy sources. Appl. Environ. Microbiol. 37, 1142-1151.

Andersen, N. M., Poehlsgaard, J., Warrass, R., and Douthwaite, S. (2012). Inhibition of protein synthesis on the ribosome comparing tildipirosin with other veterinary macrolides. Antimicrob. Agents Chemother. 56, 6033-6036.

Bozdogan, B., Galopin, S., and Leclercq, R. (2004). Characterization of a new erm-related macrolide resistance gene present in probiotic strains of Bacillus clausii. Appl. Environ. Microbiol. 70, 280-284.

Canh, T. T., Verstegen, M. W. A., Aarnink, A. J. A., and Schrama, J. W. (1997). Influence of dietary factors on nitrogen partitioning and composition of urine and feces of fattening pigs. J. Anim. Sci. 75, 700-706.

Checkley, S. L., Campbell, J. R., Chirino-Trejo, M., Janzen, E. D., and Waldner, C. L. (2010). Associations between antimicrobial use and the prevalence of antimicrobial resistance in fecal Escherichia coli from feedlot cattle in western Canada. Can. Vet. J. 51, 853-861.

Chen, J., Fluharty, F. L., St-Pierre, N., Morrison, M., and Yu, Z. (2008). Technical note: occurrence in fecal microbiota of genes conferring resistance to both macrolidelincosamide-streptogramin B and tetracyclines concomitant with feeding of beef cattle with tylosin. J. Anim. Sci. 86, 2385-2391.

Chen, J., Yu, Z., Michel F. C. Jr., Wittum, T., and Morrison, M. (2007). Development and application of real-time PCR assays 
for quantification of erm genes conferring resistance to macrolideslincosamides-streptogramin B in livestock manure and manure management systems. Appl. Environ. Microbiol. 73, 4407-4416.

CIPARS. (2013). Canadian Integrated Program for Antimicrobial Resistance Surveillance Report. Available online at: http://www. phac-aspc.gc.ca/cipars-ca/ciparspicra/pubs-eng.php\#ar (last accessed date: 8 March 2013).

Clinical and Laboratory Standards Institute (2008a). Performance Standards for Antimicrobial Disk and Dilution Susceptibility Tests for Bacteria Isolated from Animals; Approved Standard - 3rd Edn. Document M31-A3. Wayne, PA: Clinical and Laboratory Standards Institute.

Clinical and Laboratory Standards Institute (2008b). Methods for Antimicrobial Dilution and Disk Susceptibility Testing of Infrequently Isolated or Fastidious Bacteria; Approved Guideline. Document M45-A. Wayne, PA: Clinical and Laboratory Standards Institute.

Confer, A. W. (2009). Update on bacterial pathogenesis in BRD. Anim. Health Res. Rev. 10, 145-148.

Cox, S. R., McLaughlin, C., Fielder, A. E., Yancey, M. F., Bowersock, T. L., Garcia-Tapia, D., et al. (2010). Rapid and prolonged distribution of tulathromycin into lung homogenate and pulmonary epithelial lining fluid of Holstein calves following a single subcutaneous administration of $2.5 \mathrm{mg} / \mathrm{kg}$ body weight. Int. J. Appl. Res. Vet. Med. 8, 129-137.

Dabo, S. M., Taylor, J. D., and Confer, A. W. (2007). Pasteurella multocida and bovine respiratory disease. Anim. Health Res. Rev. 8, 129-150.

Desmolaize, B., Rose, S., Warrass, R., and Douthwaite, S. (2011). A novel Erm monomethyltransferase in antibiotic-resistant isolates of Mannheimia haemolytica and Pasteurella multocida. Mol. Microbiol. 80, 184-194.

DiPersio, L. P., and DiPersio, J. R. (2006). High rates of erythromycin and clindamycin resistance among OBGYN isolates of group B Streptococcus. Diagn. Microbiol. Infect. Dis. 54, 79-82.

Fisher, K., and Phillips, C. (2009). The ecology, epidemiology and virulence of Enterococcus. Microbiol. 55, 1749-1757.

Food and Drug Administration's Center for Veterinary Medicine (FDA/CVM). (2013). Tulathromycin solution for parenteral injection for treatment of bovine and swine respiratory diseases: microbiological effects on bacteria of human health concern, a qualitative risk estimation. Available online at: www.fda.gov/downloads/ AdvisoryCommittees/Committees MeetingMaterials/VeterinaryMedi cineAdvisoryCommittee/UCM127 196.pdf (last accessed date: 8 March 2013).

Frank, G. H., Briggs, R. E., Loan, R. W., Purdy, C. W., and Zehr, E. S. (2000). Effect of tilmicosin treatment on Pasteurella haemolytica organisms in nasal secretion specimens of calves with respiratory tract disease. Am. J.Vet. Res. 61, 525-529.

Fulton, R. W. (2009). Bovine respiratory disease research (1983-2009). Anim. Health Res. Rev. 10, 131-139.

Giraffa, G. (2002). Enterococci from foods. FEMS Microbiol. Rev. 26, 163-171.

Gow, S. (2005). Antimicrobial resistance, prudent use, and the Canadian integrated program for antimicrobial resistance surveillance (CIPARS). Large Anim. Vet Rounds 5, 1-6.

Heuer, O. E., Hammerum, A. M., Collignon, P., Collignon, P., and Wegener, H. C. (2006). Human health hazard from antimicrobialresistant enterococci in animals and food. Clin. Infect. Dis. 43, 911-916.

Inglis, G. D., McAllister, T. A., Busz, H. W., Yanke, L. J., Morck, D. W., Olson, M. E., et al. (2005). Effects of subtherapeutic administration of antimicrobial agents to beef cattle on the prevalence of antimicrobial resistance in Campylobacter jejuni and Campylobacter hyointestinalis. Appl. Environ. Microbiol. 71, 3872-3881.

Israeli-Reches, M., Weinrauch, Y., and Dubnau, D. (1984). Evolutionary relationships of the Bacillus licheniformis macrolidelincosamide-streptogramin B resistance elements. Mol. Gen. Genet. 194, 362-367.

Jackson, C. R., Fedorka-Cray, P. J., Barrett, J. B., and Ladely, S. R. (2004). Effects of tylosin use on erythromycin resistance in enterococci isolated from swine. Appl. Environ. Microbiol. 70, 4205-4210.

Jensen, L. B., Frimodt-Moller, N., and Aarestrup, F. M. (1999). Presence of erm gene classes in gram-positive bacteria of animal and human origin in Denmark. FEMS Microbiol. Lett. 170, 151-158.

Jensen, L. B., Hammerum, A. M. Bager, F., and Aarestrup, F. M. (2002). Streptogramin resistance among Enterococcus faecium isolated from production animals in Denmark in 1997. Microb. Drug Resist. 8, 369-374.

Katsuda, K., Kohmoto, M., Mikami, O. and Uchida, I. (2009). Antimicrobial resistance and genetic characterization of fluoroquinolone-resistant Mannheimia haemolytica isolates from cattle with bovine pneumonia. Vet. Microbiol. 139, 74-79.

Klima, C. L., Alexander, T. W., Read, R. R., Gow, S. P., Booker, C. W. Hannon, S., et al. (2011). Genetic characterization and antimicrobial susceptibility of Mannheimia haemolytica isolated from the nasopharynx of feedlot cattle. Vet. Microbiol. 149, 390-398.

Kloos, W., and Bannerman, T. L. (1994). Update on clinical significance of coagulase-negative staphylococci. Clin. Microbiol. Rev. 7, 117-140.

Kobland, J. D., Gale, G. O., Gustafson, R. H., and Simkins, K. L. (1987) Comparison of therapeutic versus subtherapeutic levels of chlortetracycline in the diet for selection of resistant salmonella in experimentally challenged chickens. Poult. Sci. 66, 1129-1137.

Ladely, S. R., Harrison, M. A., FedorkaCray, P. J., Berrang, M. E., Englen, M. D., and Meinersmann, R. J. (2007). Development of macrolideresistant Campylobacter in broilers administered subtherapeutic or therapeutic concentrations of tylosin. J. Food Prot. 70, 1945-1951.

Lewicki, J. (2006). Tylosin. A review of pharmacokinetics, residues in food animals and analytical methods. FAO website: ftp://ftp.fao.org/ag/ agn/food/tylosin2006.pdf (last accessed date: 8 March 2013).

Lim, J. A., Kwon, A. R., Kim, S. K., Chong, Y., Lee, K., and Choi, E. C. (2002). Prevalence of resistance to macrolide, lincosamide and streptogramin antibiotics in Grampositive cocci isolated in a Korean hospital. J. Antimicrob. Chemother. 49, 489-495.

Loy, T., Wilson, C., Bailey, D. Klopfenstein, T. J., and Moxley, R. A. (2001). Influence of restricted intake and reduced dietary starch on colonic $\mathrm{pH}$ and $E$. coli prevalence. Nebraska Beef Report MP76-A, 86-88.

Marshall, B. M., and Levy, S. B. (2011) Food animals and antimicrobials: impacts on human health. Clin. Microbiol. Rev. 24, 718-733.

Mao, J. C., and Putterman, M. (1968). Accumulation in gram-postive and gram-negative bacteria as a mechanism of resistance to erythromycin. J. Bacteriol. 95 1111-1117.

McEwen, S. A., and Fedorka-Cray, P. J. (2002). Antimicrobial use and resistance in animals. Clin. Infect. Dis. 34, S93-S106.

Michael, G. B., Kadlec, K., Sweeney, M. T., Brzuszkiewicz, E., Liesegang, H., Daniel, R., et al. (2012). ICEPmu1, an integrative conjugative element (ICE) of Pasteurella multocida: analysis of the regions that comprise 12 antimicrobial resistance genes. J. Antimicrob. Chemother. 67, 84-90.

Pardon, B., De Bleecker, K., Dewulf, J., Callens, J., Boyen, F., Catry, B., et al. (2011). Prevalence of respiratory pathogens in diseased, nonvaccinated, routinely medicated veal calves. Vet. Rec. 169, 278.

Piette, A., and Verschraegen, G. (2008). Role of coagulase-negative staphylococci in human disease. Vet Microbiol. 134, 45-54.

Portis, E., Lindeman, C., Johansen, L. and Stoltman, G. (2012). A ten-year (2000-2009) study of antimicrobial susceptibility of bacteria that cause bovine respiratory disease complex-Mannheimia haemolytica, Pasteurella multocida, and Histophilus somni-in the United States and Canada. J. Vet. Diagn. Invest. 24, 932-944.

Roberts, M. C. (2008). Update on macrolide-lincosamidestreptogramin, ketolide, and oxazolidinone resistance genes FEMS Microbiol. Lett. 282, 147-159

Roberts, M. C., Sutcliffe, J., Courvalin, P., Jensen, L. B., Rood, J., and Seppala, H. (1999). Nomenclature for macrolide and macrolide-lincosamidestreptogramin B resistance determinants. Antimicrob. Agents Chemother. 43, 2823-2830.

Savini, V., Catavitello, C., Carlino, D., Bianco, A., Pompilio, A., Balbinot, A., et al. (2009). Staphylococcus pasteuri bacteraemia in a patient with leukaemia. J. Clin.Pathol. 62, 957-958.

SchjØrring, S., and Krogfelt, K. A. (2011). Assessment of bacterial antibiotic resistance transfer in the gut. Int. J. Microbiol. 2011:ID 312956. doi: 10.1155/2011/312956

Schlünzen, F., Zarivach, R., Harms, J., Bashan, A., Tocilj, A., Albrecht, R., et al. (2001). Structural basis for the interaction of antibiotics with the peptidyl transferase centre in eubacteria. Nature 413, 814-821.

Scott, T., Wilson, C., Bailey, D., Klopfendtein, T. J., and Milton, T. (2000). Influence of diet on total and acid resistant E. coli and colonic 
pH. Nebraska Beef Report MP73-A, 39-43.

Siegel, T. W., Earley, D. L., Smothers, C. D., Sun, F., and Ricketts, A. P. (2004). Cellular uptake of the triamilide tulathromycin by bovine and porcine phagocytic cells in vitro. J. Anim. Sci. 82, 186

Simeoni, D., Rizzotti, L., Cocconcelli, P., Gazzola, S., Dellaglio, F., and Torriani, S. (2008). Antibiotic resistance genes and identification of staphylococci collected from the production chain of swine meat commodities. Food Microbiol. 25, 196-201.

Skinner, R., Cundliffe, E., and Schmidt, F. J. (1983). Site of action of a ribosomal RNA methylase responsible for resistance to erythromycin and other antibiotics. J. Biol. Chem. 258, 12702-12706.

Szczepanowski, R., Linke, B., Krahn, I., Gartemann, K. H., Gützkow, T., Eichler, W., et al. (2009). Detection of 140 clinically relevant antibiotic-resistance genes in the plasmid metagenome of wastewater treatment plant bacteria showing reduced susceptibility to selected antibiotics. Microbiol. 155, 2306-2319.
Turabelidze, D., Kotetishvili, M., Kreger, A., Morris, J. G. Jr., and Sulakvelidze, A. (2000). Improved pulsed-field gel electrophoresis for typing vancomycin-resistant enterococci. J. Clin. Microbiol. 38, 4242-4245.

USDA. (1999). Report part III: health management and biosecurity in U.S. feedlots 1999. Available online at: http://www.aphis.usda.gov/animal_ health/nahms/feedlot/downloads/ feedlot99/Feedlot99_dr_PartIII.pdf (last accessed date: 8 March 2013).

van Schaik, W., and Willems, R. J. (2010). Genome-based insights into the evolution of enterococci. Clin. Microbiol. Infect. 16, 527-532.

Watts, J. L., and Sweeney, M. T. (2010). Antimicrobial resistance in bovine respiratory disease pathogens: measures, trends, and impact on efficacy. Vet. Clin. North Am. Food Anim. Pract. 26, 79-88.

Wegener, H. C., Aarestrup, F. M., Jensen, L. B., Hammerum, A. M., and Bager, F. (1999). Use of antimicrobial growth promoters in food animals and Enterococcus faecium resistance to therapeutic antimicrobial drugs in Europe. Emerg. Infect. Dis. 5, 329-335.
Werner, G., Hildebrandt, B., Klare, I., and Witte, W. (2000). Linkage of determinants for streptogramin A, macrolidelincosamide-streptogramin $\mathrm{B}$, and chloramphenicol resistance on a conjugative plasmid in Enterococcus faecium and dissemination of this cluster among streptograminresistant enterococci. Int. J. Med. Microbiol. 290, 543-548.

Yost, C. K., Diarra, M. S., and Topp E. (2011). "Animals and humans as sources of fecal indicator bacteria," in The Fecal Bacteria, eds M. J. Sadowsky and R. L. Whitman (Washington DC: ASM Press), 67-91.

Zaheer, R., Yanke, L. J., Church, D., Topp, E., Read, R. R., and McAllister, T. A. (2012). Highthroughput species identification of enterococci using pyrosequencing. J. Microbiol. Methods 89, 174-178.

Zecchinon, L., Fett, T., and Desmecht, D. (2005). How Mannheimia haemolytica defeats host defence through a kiss of death mechanism. Vet. Res. 36, 133-156.

Conflict of Interest Statement: The authors declare that the research was conducted in the absence of any commercial or financial relationships that could be construed as a potential conflict of interest.

Received: 28 March 2013; paper pending published: 04 April 2013; accepted: 06 May 2013; published online: 27 May 2013.

Citation: Zaheer R, Cook SR, Klima CL, Stanford K, Alexander T, Topp E, Read $R R$ and McAllister TA (2013) Effect of subtherapeutic vs. therapeutic administration of macrolides on antimicrobial resistance in Mannheimia haemolytica and enterococci isolated from beef cattle. Front. Microbiol. 4:133. doi: 10.3389/ fmicb.2013.00133

This article was submitted to Frontiers in Antimicrobials, Resistance and Chemotherapy, a specialty of Frontiers in Microbiology.

Copyright (® 2013 Zaheer, Cook, Klima, Stanford, Alexander, Topp, Read and McAllister. This is an open-access article distributed under the terms of the Creative Commons Attribution License, which permits use, distribution and reproduction in other forums, provided the original authors and source are credited and subject to any copyright notices concerning any third-party graphics etc. 